\title{
Polycyclic Aromatic Hydrocarbons in Various Species of Fishes from Mumbai Harbour, India, and Their Dietary Intake Concentration to Human
}

\author{
V. Dhananjayan ${ }^{1,2}$ and S. Muralidharan ${ }^{1}$ \\ ${ }^{1}$ Division of Ecotoxicology, Sálim Ali Centre for Ornithology and Natural History, Coimbatore 641108, India \\ ${ }^{2}$ Regional Occupational Health Center, ICMR, Kannamangala Post, Poojanahalli Road, Devenahalli TK, Bangalore 562110, India
}

Correspondence should be addressed to V. Dhananjayan, dhananjayan_v@yahoo.com

Received 22 November 2011; Revised 30 January 2012; Accepted 8 February 2012

Academic Editor: Swadhin Behera

Copyright (C) 2012 V. Dhananjayan and S. Muralidharan. This is an open access article distributed under the Creative Commons Attribution License, which permits unrestricted use, distribution, and reproduction in any medium, provided the original work is properly cited.

\begin{abstract}
Polycyclic aromatic hydrocarbons (PAHs) are ubiquitous environmental contaminants which have caused worldwide concerns as toxic pollutant. This study reports the concentrations of $15 \mathrm{PAHs}$ in 5 species of fish samples collected along the harbour line, Mumbai, between 2006 and 2008. Among 5 species of fish investigated, Mandeli, Coilia dussimieri, detected the maximum concentration of PAHs $(P<0.05)$ followed by Doma, Otolithes ruber. The concentration of total and carcinogenic PAHs ranged from 17.43 to $70.44 \mathrm{ng} / \mathrm{g}$ wet wt. and 9.49 to $31.23 \mathrm{ng} / \mathrm{g}$ wet wt, respectively, among the species tested. The lower-molecular-weight PAHs were detected at highest levels. Estimated intakes of PAHs by fish consumption for the general population were ranged between 1.77 and $10.70 \mathrm{ng} / \mathrm{kg}$ body weight/day. Mandeli contributed to the highest intakes of PAHs. The toxic equivalents (TEQs) of PAHs were calculated using a TEQ proposed in literature, and the intake ranged from 8.39 to $15.78 \mathrm{pg}$ TEQ $/ \mathrm{kg}$ body weight $/ \mathrm{d}$. The estimated excess cancer risk value $\left(2.37 \times 10^{-7}-1.43 \times 10^{-6}\right)$ from fish consumption for the general population exceeded the guideline value $\left(1.0 \times 10^{-6}\right)$ for potential cancer risk.
\end{abstract}

\section{Introduction}

Polycyclic aromatic hydrocarbons (PAHs) are ubiquitous anthropogenic pollutants that can be biologically amplified to high concentrations in food webs. Due to their lipophilicity, persistence, and high toxicity, these residues are readily accumulated in the tissues of nontarget living organisms where they may cause detrimental effects. PAHs are toxic, carcinogenic, and mutagenic to all organisms, including humans $[1,2]$. The metabolites of PAHs may bind to proteins and DNA, which causes biochemical disruption and cell damage in animals and cancer in human [2]. The main sources of these contaminants in the environment include forest fire, natural petroleum seeps, combustion of fossil fuels, coal burning, and use of oil for cooking and heating $[3,4]$. Other sources include domestic and industrial waste waters and sewage. As a consequence, environmental contamination by PAHs has steadily increased in recent years [5].
Dietary intake has been reported as an important route for human exposure to PAHs, except for smokers and occupationally exposed populations $[6,7]$. Pollution by persistent chemicals is potentially harmful to the organisms at higher tropic levels in the food chain. The marine organisms like fish are able to accumulate severalfold higher concentration of PAHs than the surrounding water [8-10]. Fish is a major source of proteins and healthy lipids for people. In particular, the long-chain omega- 3 fatty acids have been shown to have numerous beneficial roles in the human health [11]. Despite the human benefits of a fish diet, an issue of concern related to frequent fish consumption is the potential risk arising from exposure to toxic chemicals $[12,13]$. In a recent year, a number of epidemiologic studies have reported that a large portion of human cancers, such as lung and prostate cancers, are attributable to dietary sources $[14,15]$. Certain groups of population may have higher risks from dietary exposure of PAHs than the general populations [16]. 


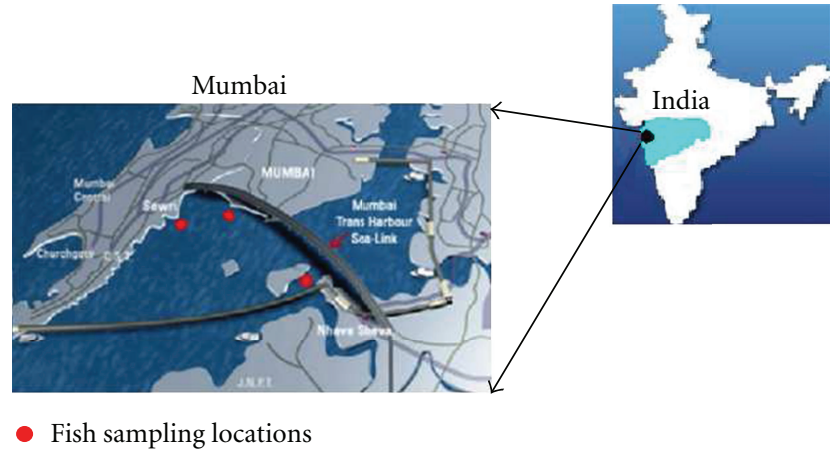

FIgURE 1: Study area showing fish samples collection locations at Mumbai harbor line, Maharashtra, India.

In India there are many studies on the presence of petroleum hydrocarbons in the Goa coastal water [17], north-west coastal water $[18,19]$, fish and prawn from north west coast of India [20], bivalve in east coast of India [21], freshwater and fish $[22,23]$, soil and sediment [24], and marine environment of Mumbai [25]. However, there is no information available concerning dietary intake of PAHs and their risk from fish consumption. The preset study was aimed at assessment of PAHs in five species of fish collected along the harbor line and estimate the cancer risk of PAHs through fish consumption using the risk assessment guideline of the United States Environmental Protection Agency [26].

\section{Materials and Methods}

2.1. Study Area. Mumbai is one of the major cities in India which is located along the western coast of the country. City with a human population density of 25,000 persons $/ \mathrm{km}^{-2}$ generates $2.2 \times 10^{6} \mathrm{~m}^{3} \mathrm{~d}^{-1}$ of domestic sewage out of which about $2 \times 10^{6} \mathrm{~m}^{3} \mathrm{~d}^{-1}$ enters marine waters including creeks and bays, largely untreated [27]. It has great diversification of industries in metropolitan region. About $8 \%$ of industries in the country are located around Mumbai in the upstream. A variety of industries, including refineries and petrochemical complexes, from this area release their effluents largely untreated into the sea. There are number of ports wherein the ship and cargo handling activities contribute to marine pollution. Sewri-Mahul and Nhava mudflats about 1000 ha have been identified as an important bird area (IBA) [28]. Sewri-Mahul mudflats $\left(19^{\circ} 01^{\prime} 00^{\prime \prime} \mathrm{N}, 72^{\circ} 52^{\prime} 60^{\prime \prime} \mathrm{E}\right.$ ) (Figure 1) extent over an area of $10 \mathrm{~km}$ long and $3 \mathrm{~km}$ wide is dominated by mangroves all along the coast. The Sewri Bay is situated just off the wide mouth of the Thane Creek along the northern periphery of Mumbai's eastern harbour. These locations were selected for fish collection.

2.2. Sample Collection. Five species of fish samples were collected between 2006 and 2008. Species which were commonly available, namely Eleutheronema tetradactylum, Coilia dussumieri, Otolithes ruber, Sardinella longiceps, and Mystus seenghala in the study locations were collected with the help of local fisherman of the region, and the morphometry measurements were taken immediately (Table 1). On collection, fish samples were stored in pollution-free sealed polythene covers and transported to the laboratory at SACON, Coimbatore, in ice box and stored at $-20^{\circ} \mathrm{C}$ in the deep freezer until analysis.

2.3. Sample Processing. Fish samples were taken out from the deep freezer, thawed, and well cleaned in tap water to remove any external dirt. Dissection was performed on thawed fish, using solvent rinsed instruments and glass dishes. The scales were sloughed off and muscle tissues were dissected between the pectoral fin and vent of the fish, minced into smaller pieces, and a subsample was taken from the homogenate. Fish parts were then placed in solvent rinsed glass jars with solvent rinsed aluminium foil lined lids. Information regarding sampled location, species, lipid content, length, and weight is presented in Table 1. Ten gram of the sample was weighed using a top loading electronic balance (Mettler AE420) and ground with anhydrous sodium sulphate $(40 \mathrm{~g})$, and the mixture was packed in a thimble (Whatman) and desiccated overnight prior to extraction. The desiccated thimble was loaded in a Soxhlet apparatus and extracted with dichloromethane (DCM) for 7 hrs. The solvent was reduced $(11 \mathrm{~mL})$, and an aliquot $(1 \mathrm{~mL})$ was taken for lipid estimation. Another aliquot $(10 \mathrm{~mL})$ was subjected to removal of other contaminants by passing the sample through a glass column packed with florisil and eluted with $100 \mathrm{~mL}$ of DCM and hexane mixture $(2: 8)$. Then the extracts were concentrated using rotary flask evaporation to a final volume of $1 \mathrm{~mL}$ in acetonitrile and filtered using $0.45 \mu \mathrm{m}$ syringe filter units. The eluant was blown using nitrogen, redissolved in $2 \mathrm{~mL} \mathrm{CAN}$, and transferred into HPLC autosampler vials for PAH analysis.

2.4. Lipid Estimation. One $\mathrm{mL}$ aliquot of sample was subjected to gravimetric determination of percent lipid content.

2.5. Estimation of PAHs. Samples were analyzed in the laboratory at Sálim Ali Centre for Ornithology and Natural History (SACON), Coimbatore, India. All the samples were quantified for 15 components of PAHs (naphthalene, acenaphthene, fluorene, phenanthrene, anthracene, fluoranthene, pyrene, benz $[a]$ anthracene, chrysene, benzo $[b]$ fluoranthene, benzo $[k]$ fluoranthene, benzo $[a]$ pyrene, dibenzo $[a, h]$ anthracene, benzo $[g, h, i]$ perylene, and indeno[1,2,3-cd]pyrene) using HPLC with programmable fluorescence detection at excited and emission wavelengths of 260 and $500 \mathrm{~nm}$, respectively. About $20 \mu \mathrm{L}$ of sample was injected through an autosampler into C18 column (Zorbax $4.6 \times 250 \mathrm{~mm}$ ) of $5 \mu \mathrm{m}$ particle size. The temperature of the column was maintained at $20^{\circ} \mathrm{C}$. Water/acetonitrile $(\mathrm{ACN})$ was used as mobile phase with a flow of $1 \mathrm{~mL} / \mathrm{min}$. The initial content of $\mathrm{ACN}$ was $50 \%$ and then increased into $60 \%(0-3 \mathrm{~min})$ and $95 \%(3-14 \mathrm{~min})$. These levels were held constant for 24 minutes until the end of the analysis. Recoveries of the compounds from fortified samples $(50 \mathrm{ppb})$ ranged from $78 \%$ to $94 \%$, and the concentrations were not corrected for percent recovery. Concentrations of PAHs are reported on 
TABLE 1: List of fish species included in the present study.

\begin{tabular}{|c|c|c|c|c|c|c|}
\hline S. no. & $\begin{array}{c}\text { Vernacular } \\
\text { name (Marathi) }\end{array}$ & Scientific name & Place of collection & $n$ & $\begin{array}{c}\text { Length }(\mathrm{cm}) \\
\text { mean } \pm \mathrm{SD}\end{array}$ & $\begin{array}{l}\text { Weight }(\mathrm{g}) \\
\text { mean } \pm \mathrm{SD}\end{array}$ \\
\hline 1 & Doma & Otolithes ruber & $\mathrm{S}, \mathrm{M}, \mathrm{N}$ & 22 & $17.9 \pm 3.53$ & $66.6 \pm 37.5$ \\
\hline 2 & Mandeli & Coilia dussumieri & $\mathrm{S}, \mathrm{M}, \mathrm{N}$ & 77 & $15.4 \pm 1.73$ & $11.5 \pm 3.22$ \\
\hline 3 & Mathi & Sardinella longiceps & S, M & 24 & $21.5 \pm 1.00$ & $102 \pm 5.42$ \\
\hline 4 & Ravas & Eleutheronema Tetradactylum & S, M & 8 & $21.6 \pm 8.02$ & $138 \pm 16.1$ \\
\hline 5 & Singala & Mystus seenghala & $\mathrm{M}, \mathrm{N}$ & 11 & $17.3 \pm 4.58$ & $36.7 \pm 6.14$ \\
\hline
\end{tabular}

$n=$ Number of samples collected, $\mathrm{S}=$ Sewri, $\mathrm{M}=$ Mahul, $\mathrm{N}=$ Nhava.

a wet weight basis. Analyses were run in batches of 10 samples plus four quality controls (QCs) including one reagent blank, one matrix blank, one QC check sample, and one random sample in duplicate. The minimum detection limit for all the compounds analysed was $0.5 \mathrm{ng} / \mathrm{g}$ wet wt.

2.6. Estimation of Dietary Intake of PAHs through Fish. Dietary intake concentration was calculated by multiplying the $\mathrm{PAH}$ concentration measured in each species of fish by the per capita consumption. The World Health Organization (WHO) has recommended a minimum $11 \mathrm{~kg}$ fish consumption per capita per annum in India $[29,30]$.

2.7. Estimation of TEQ. Some PAHs are aryl-hydrocarbon receptors agonists and potent inducers of ethoxyresorufinO-deethylase activity [31]. Hence, to accurately evaluate risk from intake of dioxin-like contaminants, the TEQ concentrations of PAHs, as well as polychlorinated dibenzop-dioxins and dibenzofurans ( $\mathrm{PCDD} / \mathrm{Fs})$ and dioxin-like polychlorinated biphenyls (PCBs), should be considered. The H4IIE-specific potencies, relative to tetrachlorinated dibenzo- $p$-dioxin (TCDD), have been reported of same $\mathrm{PAH}$ compounds used in this study [32]. Relative potencies of $\mathrm{BaA}, \mathrm{Chr}, \mathrm{BbF}, \mathrm{BkF}, \mathrm{BaP}, \mathrm{InP}$, and $\mathrm{DbA}$ are 0.000025 , $0.0002,0.00253,0.00478,0.000354,0.0011$, and 0.00203 , respectively [33], and these values were used to estimate TEQs contributed by PAHs (TEQ-PAHs).

2.8. Determination of Cancer Risk Factor. The public concern regarding exposure to PAHs is associated with its potential carcinogenicity in humans $[14,15]$. The potential health risks of ingesting fish contaminated with carcinogenic contaminates were evaluated for the Mumbai population using the risk assessment guideline of the USEPA [26]. The mean dietary intakes of the seven PAHs are considered probable human carcinogens by the US EPA, and hence they are considered. The general equation for estimating exposure, through ingestion of fish is as follows:

$$
\text { Excess cancer risk }=\frac{\mathrm{EI} \cdot \mathrm{ED} \cdot \mathrm{CSF}}{\mathrm{BW} \cdot \mathrm{AT}},
$$

where EI is estimated intake $(\mathrm{mg} / \mathrm{kg} / \mathrm{d})$, ED is exposure duration (years; adults $=30$ years), CSF is the oral cancer slope factor $\left((\mathrm{mg} / \mathrm{kg} / \mathrm{d})^{-1}\right)$, BW is human body weight (assuming $60 \mathrm{~kg}$ weight), and AT is the average time for carcinogens (years, assuming 70 years for adults). The CSF

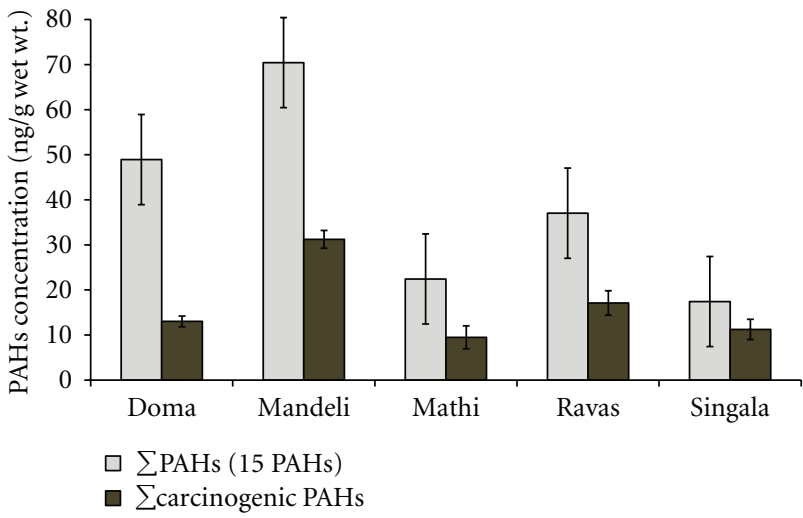

Figure 2: Concentration of carcinogenic PAHs and total PAHs among various species of fish along harbor line, Mumbai, India.

data for individual PAHs, obtained from the integrated risk information system reported by the USEPA (2004), are BaA (0.73), Chr (0.0073), Bbf (0.73), BkF (0.073), BaP (7.3), InP (0.73), and $\mathrm{DbA}(7.3)$.

2.9. Statistics. All the data were log transformed to get normal distribution. One Way Analysis of Variance (ANOVA) was performed to assess the variation among species. Means were compared using the Bonferroni multiple comparison test. The significant level was $P<0.05$. All the calculations were done using statistical software, SPSS student version 10.

\section{Results and Discussion}

3.1. Concentration of PAHs among Fish Species. Concentration of lipids estimated and individuals components of PAHs among fish species in harbor line, Mumbai, collected between 2006 and 2008 are listed in Table 2. The lipid content of fish samples ranged from $3.3 \%$ to $4.4 \%$ on wet weight basis. The concentration of total PAHs ( $\sum \mathrm{PAH}$ (the sum of 15 PAHs) ) and carcinogenic PAHs ( $\sum \mathrm{CPAH}$ (the sum of $\mathrm{BaA}, \mathrm{BbF}, \mathrm{BkF}, \mathrm{BaP}, \mathrm{InP}$, and $\mathrm{DbA})$ ) are presented in Figure 2. The levels of $\sum \mathrm{PAH}$ and $\sum \mathrm{CPAH}$ ranged from 17.43 to $70.44 \mathrm{ng} / \mathrm{g}$ wet wt. and 9.49 to $31.23 \mathrm{ng} / \mathrm{g}$ wet $\mathrm{wt}$, respectively. The maximum concentration of $\sum \mathrm{PAH}$ in marine fish species was found in Coilia dussumieri (70.44 ng/g wet wt.) $(P<0.05)$. Other species such as Otolithes ruber, Eleutheronema tetradactylum and Mystus seenghala detected relatively 
TABLE 2: Concentration (mean $\pm \mathrm{SD}$ ) of PAHs among fish from the Mumbai transharbour, Maharashtra, India.

\begin{tabular}{|c|c|c|c|c|c|}
\hline $\begin{array}{l}\text { Fishes } \Rightarrow \\
\text { PAHs } \Downarrow \\
\end{array}$ & Doma $(n=22)$ & Mandeli* $(n=77)$ & Mathi $(n=24)$ & Ravas $(n=8)$ & Singala $(n=11)$ \\
\hline Lipid content (\%) & 3.9 & 4.4 & 3.3 & 3.7 & 4.1 \\
\hline Naphthalene & $19.94 \pm 6.12$ & $43.14 \pm 10.9$ & $17.67 \pm 6.78$ & $14.04 \pm 6.36$ & $25.7 \pm 8.22$ \\
\hline Acenaphthene & $2.98 \pm 1.68$ & $5.48 \pm 3.24$ & $1.30 \pm 1.06$ & $6.13 \pm 4.16$ & ND \\
\hline Fluorene & $5.36 \pm 2.91$ & $4.84 \pm 3.01$ & $4.10 \pm 2.39$ & ND & $6.70 \pm 3.47$ \\
\hline Phenanthrene & $0.61 \pm 0.52$ & $0.99 \pm 0.52$ & ND & ND & ND \\
\hline Anthracene & ND & ND & ND & $1.89 \pm 0.98$ & ND \\
\hline Fluoranthene & $2.17 \pm 1.05$ & $2.10 \pm 1.72$ & $3.20 \pm 1.94$ & $5.20 \pm 2.47$ & $3.24 \pm 1.69$ \\
\hline Pyrene & $1.64 \pm 1.37$ & ND & ND & ND & ND \\
\hline Benz[a]anthracene & ND & ND & ND & ND & ND \\
\hline Chrysene & ND & $8.85 \pm 3.56$ & ND & $2.79 \pm 1.11$ & ND \\
\hline Benzo[b]fluoranthene & $1.20 \pm 0.93$ & $3.71 \pm 1.85$ & ND & $3.46 \pm 1.08$ & ND \\
\hline Benzo $[\mathrm{k}]$ fluoranthene & $2.72 \pm 1.24$ & ND & $3.54 \pm 2.88$ & ND & $5.67 \pm 3.78$ \\
\hline Benz[a]pyrene & ND & ND & ND & $1.25 \pm 0.87$ & ND \\
\hline Dibenzo[a,h]anthracene & $4.44 \pm 3.21$ & $5.53 \pm 2.40$ & ND & $3.70 \pm 2.07$ & $1.27 \pm 0.78$ \\
\hline Benzo[g,h,i]perylene & $2.06 \pm 1.92$ & $3.61 \pm 1.99$ & $4.61 \pm 2.31$ & $3.15 \pm 2.10$ & $1.83 \pm 0.67$ \\
\hline Indeno[1,2,3-cd]pyrene & ND & $3.23 \pm 2.13$ & ND & ND & $1.73 \pm 1.02$ \\
\hline
\end{tabular}

*ANOVA, $P<0.05$. ND = not detected (below detectable limits).

equal concentration, whereas the minimum concentration was detected in Sardinella longiceps.

The total PAHs concentration reported in fish samples of the present study appears to be higher than the concentration reported in edible fishes $(0.207-3.365 \mathrm{ppm})$ of the Gomti river, Lucknow, India [23]. The $\sum \mathrm{PAHs}$ concentration detected in the fishes of present study is comparable with study reported in the muscles of the fish, from fish pound of the Pearl river delta (49.59 ng/g wet wt) [34] and lower than the levels in the Mai Po Marshes Nature Reserve of Hong Kong (497 ng/g wet wt.) [35]. However, higher levels reported in the fish muscles from the Red Sea Coast (12.29 ng/g wet wt.) [36]. Among the various components of PAHs, naphthalene was the most frequently detected as reported in other studies $[36,37]$, followed by fluorene and acenaphthene. Benzo[b] anthracene could not be detected in any of the samples, while anthracene, pyrene, and benzo[a]pyrene were present only in one sample each. The absence or rather low detection of certain PAHs in the fish samples may be attributed to their rapid depuration or biotransformation [37]. The accumulation and depuration of PAHs in fish can be influenced by various factors including route and duration of exposure, lipid content of tissues, environmental factors, differences in species, age, and sex, and exposure to other xenobiotics [38].

3.2. Dietary Intake of PAHs through Fish Consumption. Calculated dietary intake concentration of PAHs through consumption of marine fish to human is presented in Figure 3. The average intake of PAHs through fish consumption was estimated to be $1.77-10.7 \mathrm{ng} / \mathrm{kg}$ body weight $/ \mathrm{d}$. Among fish species of fish analysed, Mandeli contributed to the highest intake of total PAHs. Estimated intakes through consumption of other species are less than $7 \mathrm{ng} / \mathrm{kg}$ body

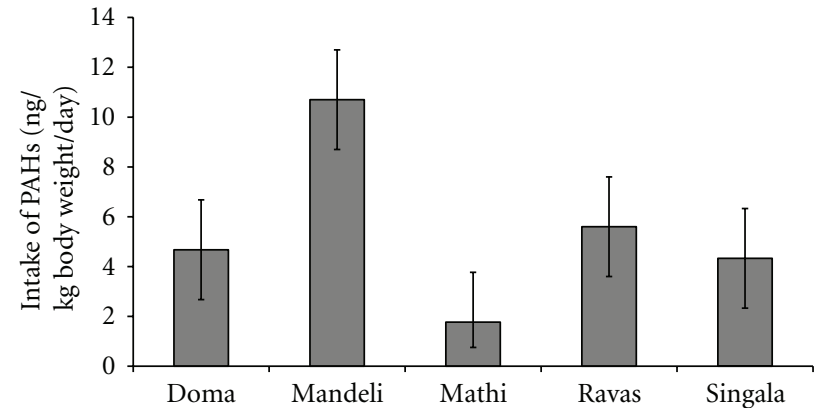

Figure 3: Calculated dietary intake concentration of PAHs through consumption of fishes from the Mumbai horbour line, Maharashtra, India.

weight/d. Only a few studies have examined dietary intakes of PAHs through fish consumption worldwide. The amount of average dietary intake of PAHs in humans through fishes estimated in Mumbai is far less compared to that in other countries. The estimated intake of PAHs from fish consumption reported for the general populations in other counties such as Spain (626-712 ng/d) [39], Kuwait (231 ng/d) [40], and Korea (13.8-16.7 ng/kg body weight/d [41]. This result seems to be associated with the consumption rate and accumulation level of PAHs in the fish available in Mumbai.

3.3. Contribution of PAHs to Total Toxic Equivalence ( $\left.\sum T E Q s\right)$. The estimated intake of TEQ-PAHs from fish consumption for the general population ranged between 8.3 and $15.78 \mathrm{pg} \mathrm{TEQ} / \mathrm{kg}$ body weight/day (Figure 4); these levels were higher than the levels reported in Korea through consumption of seafood [41]. PAHs concentration was proposed 


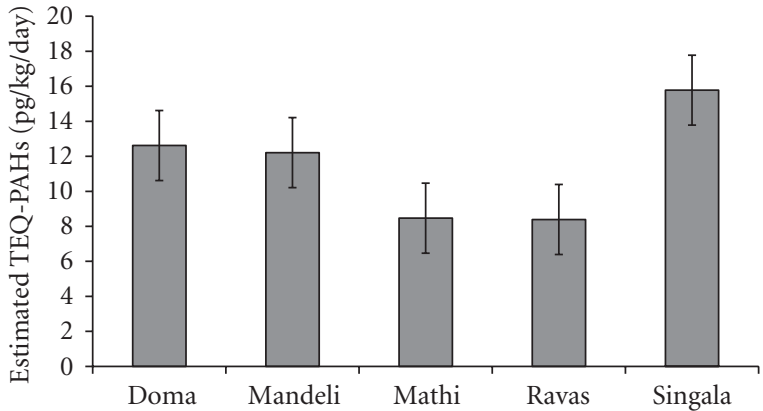

FIGURE 4: Estimated TEQ-PAHs concentration among various species of fishes from the Mumbai horbour line, Maharashtra, India.

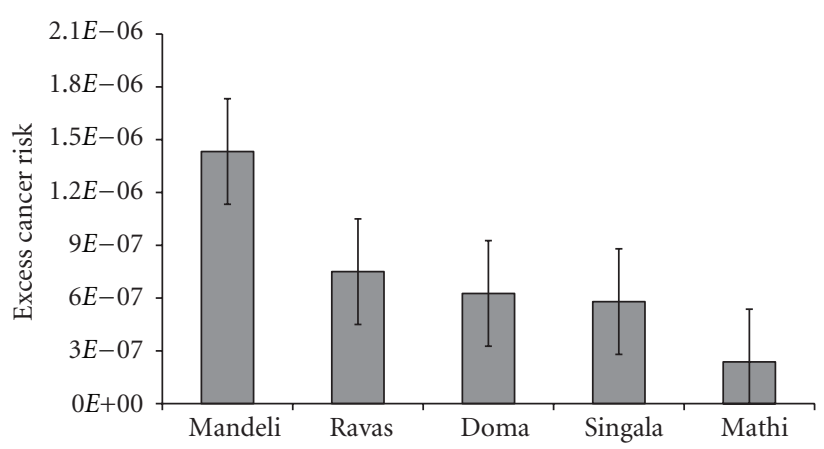

Figure 5: Calculated excess cancer risk associated with the consumption of marine fish at the Mumbai horbour line, Maharashtra, India.

as one of the toxic chemicals in food, consumer products, and the environment [32] for estimating the tolerable daily intake of $2 \mathrm{pg} \mathrm{TEQ} / \mathrm{kg}$ body weight/day by the United and European Commission [42]. Based on these results, TEQPAHs estimated in the present study was the highest contributor to total TEQ intake from fish consumption, indicating that PAHs in fish should be considered in risk assessment along with PCDD/Fs and dioxin-like PCBs.

3.4. Assessment of Excess Cancer Risk. Excess cancer risk values, estimated from individual fish consumption for the general population are presented in Figure 5. Among the fish species of fish estimated, Mandeli showed relatively higher risk values than those shown by other specie because of their high concentration of carcinogenic PAHs. The excess cancer risk values estimated for Mandeli exceeded the cancer risk guideline value $\left(1 \times 10^{-6}\right)$ [26]. This result indicates that adverse effects from PAHs in fish could only be caused by lifetime consumption of fish.

The concentration of PAHs was measured in commonly consumed types of fishes available in the study locations in Mumbai. The PAH levels in Mumbai sea were moderate compared with those found in other countries. Dominant compounds of PAHs were the lower-molecular-weight aromatics, such as naphthalene and fluorine. PAH intakes by way of fish consumption by the general population were estimated. Intake of the TEQ values calculated from
PAH concentrations showed that PAHs were the highest contributor to total TEQ intake. The estimated excess cancer risk values from fish consumption for the general population exceeded the guideline value for potential cancer risk. The results of the resent study emphasize the importance of systematically monitoring PAH levels and fish intake and comparing them with published guidelines to protect human health.

\section{Acknowledgments}

The authors sincerely thank the Maharashtra State Road Development Corporation (MSRDC), India for financial assistance. They are grateful to Drs. V. S. Vijayan, S. N. Prasad, Lalitha Vijayan, R. Jayakumar, and Miss V. R. Peter, SACON for their support. They appreciate S. Patturajan and Muragesan for their assistance in all our laboratory works.

\section{References}

[1] D. E. Nacci, M. Kohan, M. Pelletier, and E. George, "Effects of benzo[a]pyrene exposure on a fish population resistant to the toxic effects of dioxin-like compounds," Aquatic Toxicology, vol. 57, no. 4, pp. 203-215, 2002.

[2] B. Armstrong, E. Hutchinson, J. Unwin, and T. Fletcher, "Lung cancer risk after exposure to polycyclic aromatic hydrocarbons: a review and meta-analysis," Environmental Health Perspectives, vol. 112, no. 9, pp. 970-978, 2004.

[3] E. R. Christensen and P. A. Bzdusek, "PAHs in sediments of the Black River and the Ashtabula River, Ohio: source apportionment by factor analysis," Water Research, vol. 39, no. 4, pp. 511-524, 2005.

[4] H.-B. Moon, K. Kannan, S.-J. Lee, and G. Ok, "Atmospheric deposition of polycyclic aromatic hydrocarbons in an urban and a suburban area of Korea from 2002 to 2004," Archives of Environmental Contamination and Toxicology, vol. 51, no. 4, pp. 494-502, 2006.

[5] P. C. Van Metre, B. J. Mahler, and E. T. Furlong, "Urban sprawl leaves its PAH signature," Environmental Science and Technology, vol. 34, no. 19, pp. 4064-4070, 2000.

[6] G. Scherer, S. Frank, K. Riedel, I. Meger-Kossien, and T. Renner, "Biomonitoring of exposure to polycyclic aromatic hydrocarbons of nonoccupationally exposed persons," Cancer Epidemiology Biomarkers and Prevention, vol. 9, no. 4, pp. 373$380,2000$.

[7] G. Falcó, J. L. Domingo, J. M. Llobet, A. Teixidó, C. Casas, and L. Müller, "Polycyclic aromatic hydrocarbons in foods: human exposure through the diet in Catalonia, Spain," Journal of Food Protection, vol. 66, no. 12, pp. 2325-2331, 2003.

[8] R. J. Law and J. Hellou, "Contamination of fish and shellfish following oil spill incidents," Environmental Geosciences, vol. 6, no. 2, pp. 90-98, 1999.

[9] I. Vives, J. O. Grimalt, P. Fernández, and B. Rosseland, "Polycyclic aromatic hydrocarbons in fish from remote and high mountain lakes in Europe and Greenland," Science of the Total Environment, vol. 324, no. 1-3, pp. 67-77, 2004.

[10] B. Johnson-Restrepo, J. Olivero-Verbel, S. Lu et al., "Polycyclic aromatic hydrocarbons and their hydroxylated metabolites in fish bile and sediments from coastal waters of Colombia," Environmental Pollution, vol. 151, no. 3, pp. 452-459, 2008. 
[11] H. M. Ismail, "The role of omega-3 fatty acids in cardiac protection: an overview," Frontiers in Bioscience, vol. 10, pp. 1079$1088,2005$.

[12] J. L. Domingo, A. Bocio, G. Falcó, and J. M. Llobet, "Benefits and risks of fish consumption. Part I. A quantitative analysis of the intake of omega-3 fatty acids and chemical contaminants," Toxicology, vol. 230, no. 2-3, pp. 219-226, 2007.

[13] I. Sioen, J. Van Camp, F. Verdonck et al., "Probabilistic intake assessment of multiple compounds as a tool to quantify the nutritional-toxicological conflict related to seafood consumption," Chemosphere, vol. 71, no. 6, pp. 1056-1066, 2008.

[14] G. L. Ambrosini, L. Fritschi, N. H. de Klerk, D. Mackerras, and J. Leavy, "Dietary patterns identified using factor analysis and prostate cancer risk: a case control study in Western Australia," Annals of Epidemiology, vol. 18, no. 5, pp. 364-370, 2008.

[15] M. Shen, R. S. Chapman, X. He et al., "Dietary factors, food contamination and lung cancer risk in Xuanwei, China," Lung Cancer, vol. 61, no. 3, pp. 275-282, 2008.

[16] R. Martí-Cid, J. M. Llobet, V. Castell, and J. L. Domingo, "Evolution of the dietary exposure to polycyclic aromatic hydrocarbons in Catalonia, Spain," Food and Chemical Toxicology, vol. 46, no. 9, pp. 3163-3171, 2008.

[17] S. P. Fondekar, R. S. Topgi, and R. J. Noronha, "Distribution of petroleum hydrocarbons in Goa coastal waters," Indian Journal of Marine Sciences, vol. 9, no. 4, pp. 286-288, 1980.

[18] A. N. Kadam and V. P. Bhangale, "Petroleum hydrocarbons in northwest coastal waters of India," Indian Journal of Marine Sciences, vol. 22, no. 3, pp. 227-228, 1993.

[19] M. S. Shailaja, R. Rajamanickam, and S. Wahidulla, "Increased formation of carcinogenic PAH metabolites in fish promoted by nitrite," Environmental Pollution, vol. 143, no. 1, pp. 174177, 2006.

[20] P. Mehta, A. N. Kadam, S. N. Gajbhiye, and B. N. Desai, "Petroleum hydrocarbon concentration in selected species of fish and prawn form northwest coast of India," Indian Journal of Marine Science, vol. 23, no. 2, pp. 123-125, 1994.

[21] P. C. Mohan and R. R. Prakash, "Concentration of petroleum hydrocarbons in bivalve Mytilopsis sallei and in the habour waters of Visakhapatnam, east coast of India," Indian Journal of Marine Sciences, vol. 27, no. 3-4, pp. 496-498, 1998.

[22] A. Malik, K. P. Singh, D. Mohan, and D. K. Patel, "Distribution of polycyclic aromatic hydrocarbons in Gomti river system, India," Bulletin of Environmental Contamination and Toxicology, vol. 72, no. 6, pp. 1211-1218, 2004.

[23] A. Malik, P. Ojha, and K. P. Singh, "Distribution of polycyclic aromatic hydrocarbons in edible fish from Gomti river, India," Bulletin of Environmental Contamination and Toxicology, vol. 80, no. 2, pp. 134-138, 2008.

[24] S. A. Ingole, S. S. Dhaktode, and A. N. Kadam, "Determination of petroleum hydrocarbons in sediment samples from Bombay harbour, Dharamtar creek and Amba river estuary," Indian Journal of Environmental Protection, vol. 9, no. 2, pp. 118-123, 1989.

[25] M. K. Chouksey, A. N. Kadam, and M. D. Zingde, "Petroleum hydrocarbon residues in the marine environment of BasseinMumbai," Marine Pollution Bulletin, vol. 49, no. 7-8, pp. 637647,2004

[26] U.S. EPA, "Volume I. Human Health Evaluation Manual (HHEM) (Part A, Baseline Risk Assessment). Interim Final," Office of Emergency and Remedial Response, Washington, DC, USA, EPA/540/1-89/002. NTIS PB90-15558, 1989.

[27] M. D. Zingde, "Marine pollution-what are we heading for?" in Ocean Science: Trends and Future Directions, pp. 229-246, Indian National Science Academy, New Delhi, India, 1999.
[28] M. Z. Islam and A. R. Rahmani, Important Bird Areas in India: Priority Sites for Conservation, Indian Bird Conservation Network, Bombay Natural History Society and Bird life International, Oxford University Press, Oxford, UK, 2004.

[29] P. V. Dehadrai, "Aquaculture and environment," in Souvenir, National Aquaculture Week, pp. 13-16, Aquaculture Foundation of India, Chennai, India, 1997.

[30] A. Kumari, R. K. Slnha, K. Gopal, and K. Prasad, "Dietary intake of persistent organochlorine residues through gangetic fishes in India," International Journal of Ecology and Environmental Sciences, vol. 27, no. 2, pp. 117-120, 2001.

[31] D. L. Villeneuve, J. S. Khim, K. Kannan, and J. P. Giesy, "Relative potencies of individual polycyclic aromatic hydrocarbons to induce dioxinlike and estrogenic responses in three cell lines," Environmental Toxicology, vol. 17, no. 2, pp. 128-137, 2002.

[32] Committee on Toxicity (CoT) of Chemicals in Food, Consumer Products, and theEnvironment, and Food standards Agency/Department of Health, Brussel, Belgium, 2001.

[33] K. L. Willett, P. R. Gardinali, J. L. Sericano, T. L. Wade, and S. H. Safe, "Characterization of the H4IIE rat hepatoma cell bioassay for evaluation of environmental samples containing polynuclear aromatic hydrocarbons (PAHs)," Archives of Environmental Contamination and Toxicology, vol. 32, no. 4, pp. 442-448, 1997.

[34] K. Y. Kong, K. C. Cheung, C. K. C. Wong, and M. H. Wong, "The residual dynamic of polycyclic aromatic hydrocarbons and organochlorine pesticides in fishponds of the Pearl River delta, South China," Water Research, vol. 39, no. 9, pp. 1831$1843,2005$.

[35] Y. Liang, M. F. Tse, L. Young, and M. H. Wong, "Distribution patterns of polycyclic aromatic hydrocarbons (PAHs) in the sediments and fish at Mai Po Marshes Nature Reserve, Hong Kong," Water Research, vol. 41, no. 6, pp. 1303-1311, 2007.

[36] A. A. Z. DouAbul, H. M. A. Heba, and K. H. Fareed, "Polynuclear Aromatic Hydrocarbons (PAHs) in fish from the Red Sea Coast of Yemen," Hydrobiologia, vol. 352, no. 1-3, pp. 251262, 1997.

[37] S. C. Deb, T. Araki, and T. Fukushima, "Polycyclic aromatic hydrocarbons in fish organs," Marine Pollution Bulletin, vol. 40, no. 10, pp. 882-885, 2000.

[38] U. Varanasi, J. E. Stein, and M. Nishimoto, "Chemical carcinogenesis in feral fish: uptake, activation, and detoxication of organic xenobiotics," Environmental Health Perspectives, vol. 71, pp. 155-170, 1987.

[39] G. Falcó, A. Bocio, J. M. Llobet, and J. L. Domingo, "Health risks of dietary intake of environmental pollutants by elite sportsmen and sportswomen," Food and Chemical Toxicology, vol. 43, no. 12, pp. 1713-1721, 2005.

[40] T. Saeed, S. Al-Yakoob, H. Al-Hashash, and M. Al-Bahloul, "Preliminary exposure assessment for Kuwaiti consumers to polycyclic aromatic hydrocarbons in seafood," Environment International, vol. 21, no. 3, pp. 255-263, 1995.

[41] H.-B. Moon, H.-S. Kim, M. Choi, and H.-G. Choi, "Intake and potential health risk of polycyclic aromatic hydrocarbons associated with seafood consumption in Korea from 2005 to 2007," Archives of Environmental Contamination and Toxicology, vol. 58, no. 1, pp. 214-221, 2010.

[42] Scientific Committee on Food, "Opinion of the Scientific Committee on Food on the risk assessment of dioxins and dioxin-like PCBs in food," CS/CNTM/DIOXIN/20 FINAL, Brussels, Belgium, 2001, http://ec.europa.eu/food/fs/sc/scf/ out90_en.pdf. 

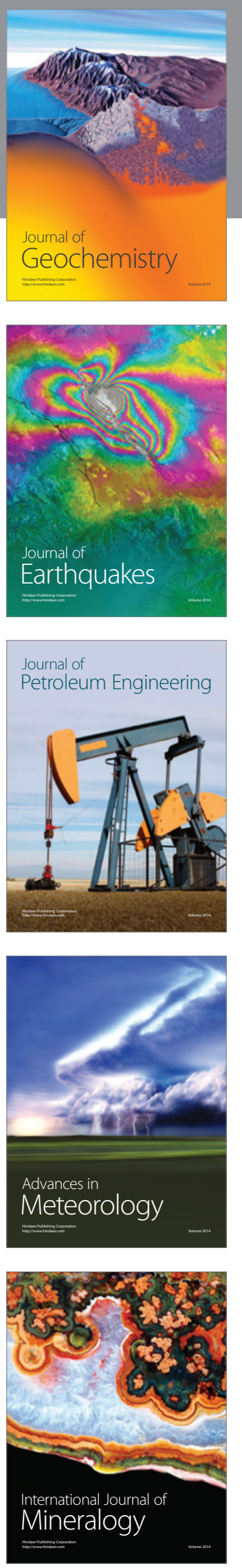
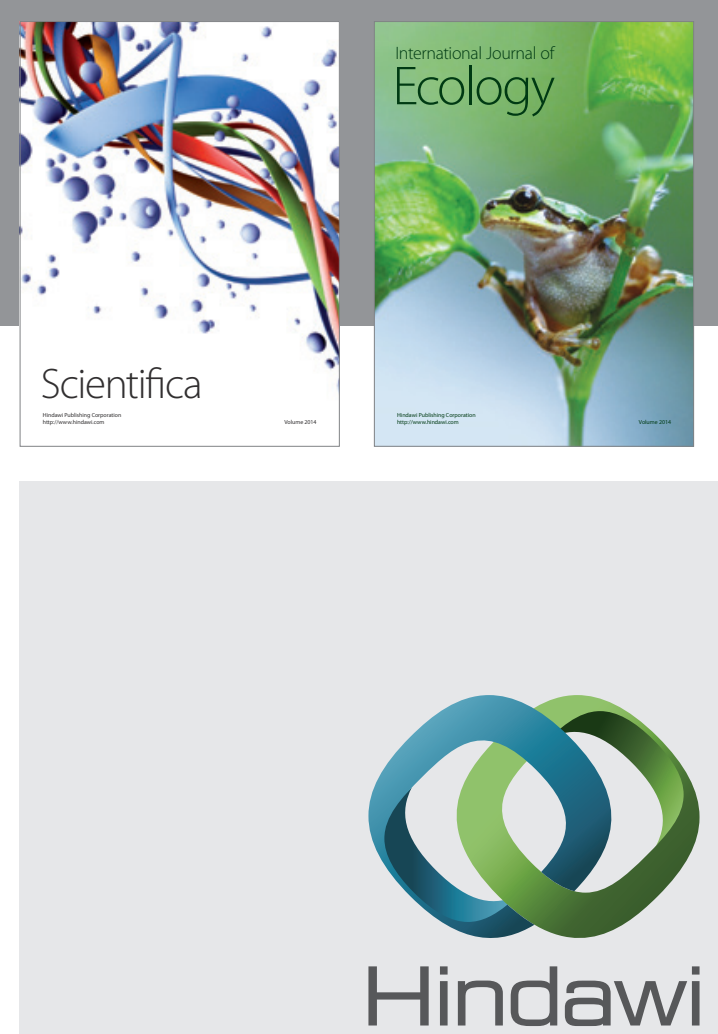

Submit your manuscripts at http://www.hindawi.com
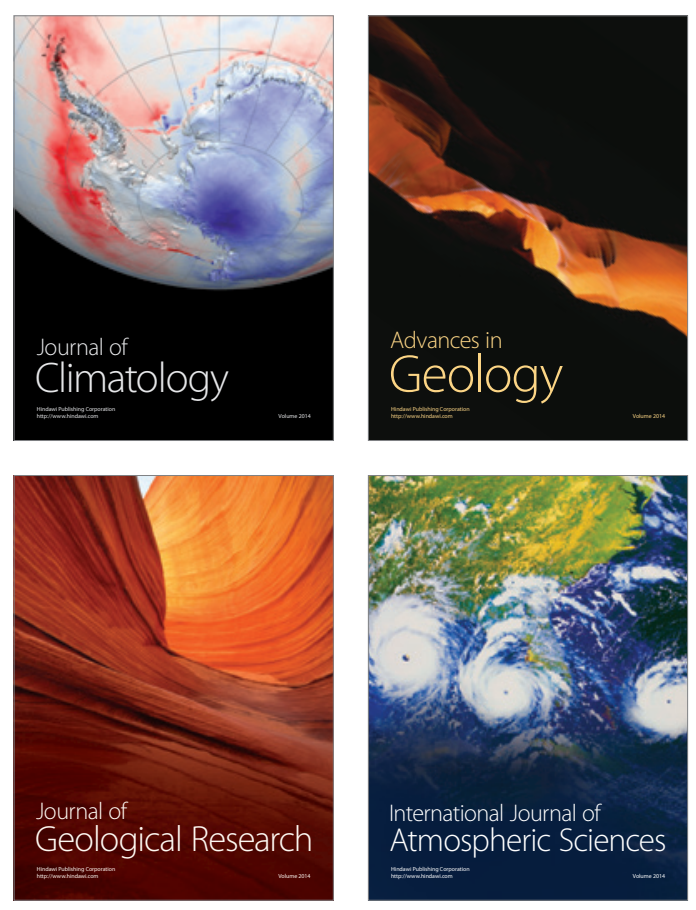
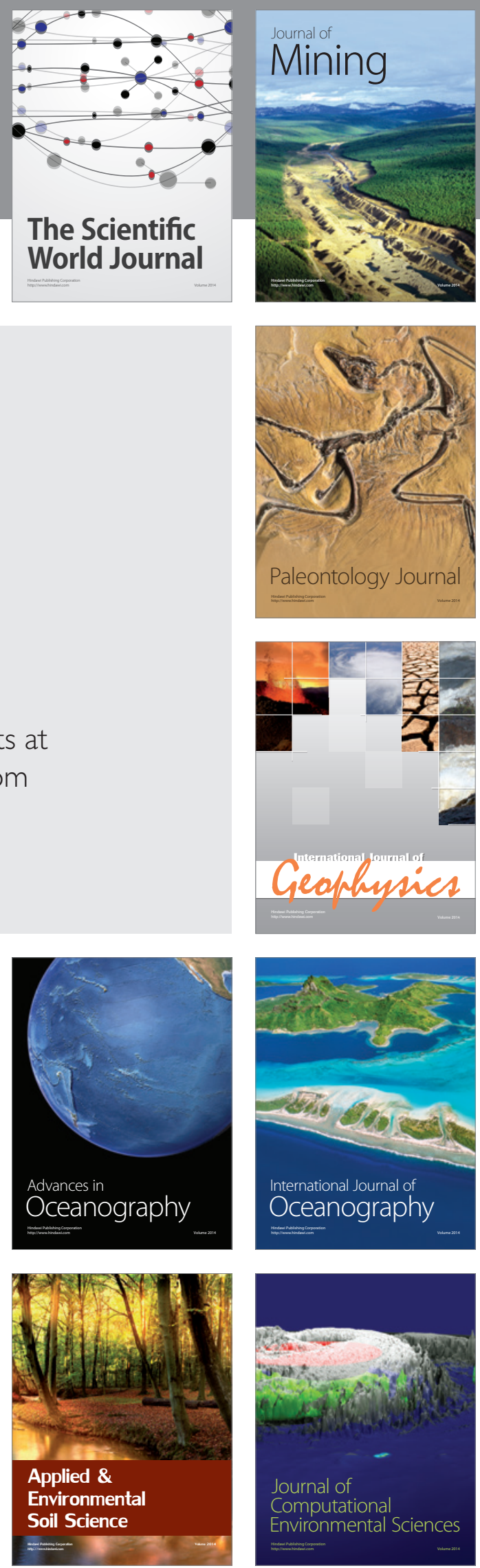